Relations industrielles

Industrial Relations

\title{
Publications récentes
}

Recent Publications

Volume 44, numéro 3, 1989

URI : https://id.erudit.org/iderudit/050530ar

DOI : https://doi.org/10.7202/050530ar

Aller au sommaire du numéro

Éditeur(s)

Département des relations industrielles de l'Université Laval

ISSN

0034-379X (imprimé)

1703-8138 (numérique)

Découvrir la revue

Citer ce document

(1989). Publications récentes. Relations industrielles / Industrial Relations, 44(3),

737-744. https://doi.org/10.7202/050530ar

Tous droits réservés (C Département des relations industrielles de l'Université Laval, 1989
Ce document est protégé par la loi sur le droit d'auteur. L’utilisation des services d'Érudit (y compris la reproduction) est assujettie à sa politique d'utilisation que vous pouvez consulter en ligne.

https://apropos.erudit.org/fr/usagers/politique-dutilisation/ 


\section{PUBLICATIONS RÉCENTES RECENT PUBLICATIONS}

\section{Théorie et système des relations industrielles}

«L'évolution des relations professionnelles en Uruguay: succès et écueils», par Arturo $S$. Bronstein, Revue internationale du travail, (Genève), vol. 128, no 2, 1989, pp. 217-237.

"Industrial Relations Agenda for Change: The Case of the United States», by Thomas A. Kochan and Kirsten R. Wever, Labour, (Roma), vol. 2, no 2, 1988, pp. 21-57.

«The Reconstruction of Soviet Industrial Relations Under Gorbachev», Marat V. Baglai talks to Noel Hibbert, Employee Relations (Bradford, England), vol. 11, no 1, 1989, pp. 10-17.

«Les nouvelles réformes économiques en URSS et leur impact sur le marché du travail», par Evgenii G. Antosenkov, Travail et société, (Genève), vol. 143, no 1, 1989, pp. 25-45.

\section{Relations du travail}

«Grèves et lock-out au Québec en 1988», par André Dompierre et Jean-Mance Martel, Le marché du travail, (Québec), vol. 10, no 5, 1989, pp. 55-69.

«Déréglementation des relations de travail et autoréglementation de l'entreprise», par Alain Supiot, Droit social, (Paris), no 3, mars 1989, pp. 195-206.

«L'expertise technologique du comité d'entreprise», par Pierre Cam et Patrick Chaumette, Droit social, (Paris), no 3, mars 1989, pp. 220-229.

«La flexibilité du travail. Réflexions sur les modèles européens», par Bernard Brunhes, Droit social, (Paris), no 3, 1989, pp. 251-256.

«One Hundred Years of Strike Statistics: Methodological and Theoretical Issues in Quantitative Strike Research", by Roberto Franzosi, Industrial and Labor Relations Review, (Cornell Univ., Ithaca, N.Y.), vol. 42, no 3, 1989, pp. 348-363.

«Who Uses Interest Arbitration? The Case of British Columbia's Teachers, 1947-1981», by Janet Currie, Industrial and Labor Relations Review, (Cornell Univ., Ithaca, N.Y.), vol. 42, no 3, 1989, pp. 363-380.

"The Impact of Bargainer Experience on Teacher Strikes», by Edward Montgomery and Mary Ellen Benedict, Industrial and Labor Relations Review, (Cornell Univ., Ithaca, N.Y.), vol. 42, no 3, 1989, pp. 380-393.

«Determinants of Grievance Outcomes: A Case Study», by Ignace Ng and Ali Dastmalchian, Industrial and Labor Relations Review, (Cornell Univ., Ithaca, N.Y.), vol. 42, no 3, 1989, pp. 393-404.

«The Impact of Unionism on Municipal Expenditures and Revenues», by Robert G. Valletta, Industrial and Labor Relations Review, (Cornell Univ., Ithaca, N.Y.), vol. 42, no 3, 1989, pp. 430-433.

«Productivity Change in the Coal Industry and the New Industrial Relations», by Ray Richardson and Stephen Wood, British Journal of Industrial Relations, (London, England), vol. XXVII, no 1, 1989, pp. 33-57. 
«Recession in the Public Sector Industrial Relations in Freightliner 1981-1985», by Christine Edwards and Edmund Heery, British Journal of Industrial Relations, (London, England), vol. XXVII, no 1, 1989, pp. 57-73.

«Sabotage at General Motors. Van Nuys Assembly Plan 1975-83», by Craig A. Zabala, Industrial Relations Journal, (Univ. of Nottingham, England), vol. 20, no 1, 1989, pp. 16-33.

«Union Recognition, Single Union Agreements and Employment Change in Scotish Electronics", by Alan Sproull and John MacInnes, Industrial Relations Journal, (Univ. of Nottingham, England), vol. 20, no 1, 1989, pp. 33-47.

«Towards Tripartism: Industrial Relations in the Steel Industry 1978 to 1987 », by Diana Kelly, The Journal of Industrial Relations, (Univ. of New South Wales, Kensington, Australia), vol. 30, no 4, 1988, pp. 511-533.

«Equal Pay and Comparable Worth and the Australian Conciliation and Arbitration Commission», by Laura Bennett, The Journal of Industrial Relations, (Univ. of New South Wales, Kensington, Australia), vol. 30, no 4, 1988, pp. 533-546.

"Consultative Councils in Quantas and Telecom: A Comparative Study», by E.M. Davis and R.D. Lansbury, The Journal of Industrial Relations, (Univ. of New South Wales, Kensington, Australia), vol. 30, no 4, 1989, pp. 546-566.

"Arbitration and Bureaucracy: The New South Wales Railway Commissioners, 1892-1914», by Greg Patmore, The Journal of Industrial Relations, (Univ. of New South Wales, Kensington, Australia), vol. 30, no 4, 1988, pp. 566-583.

«Technical Change and Industrial Relations: Theoretical Reflections on Changes in the Automobile Economy?», by Ben Dankbaar, Economic and Industrial Democracy, (Stockholm, Sweden), vol. 10, no 1, 1989, pp. 99-123.

«Industrial Discipline, the Control of Attendance, and the Subordination of Labour: Towards an Integrated Analysis", by P.K. Edwards and Colin Whitston, Work Employment and Socie$t y$, (London, England), vol. 3, no 1, 1989, pp. 1-29.

«What Do Managers Mean by Cooperative Labor Relations?», by Paula B. Voos and TsanYuang Cheng, Labor Studies Journal, (Rutgers Univ., New Brunswick, N.J.), vol. 14, no 1, 1989, pp. 3-19.

«The Implications of Cell Manufacturing for U.S. Factory Workers and their Unions», by Keith Knauss and Michael Matuszak, Labor Studies Journal, (Rutgers Univ., New Brunswick, N.J.), vol. 14, no 1, 1989, pp. 19-30.

«Political Parties and Labor Legislation in Canada and the U.S.», by Peter G. Bruce, Industrial Relations, (Univ. of California, Berkeley), vol. 28, no 2, 1989, pp. 115-142.

«Unionization and Job Design Under Programmable Automation», by Maryellen R. Kelley, Industrial Relations, (Univ. of California, Berkeley), vol. 28, no 2, 1989, pp. 174-188.

\section{Organisations syndicales et patronales}

"Managerial and Professional Employees: Conceptualising Union Strategies and Structures», by Ed Snape and Greg Bamber, British Journal of Industrial Relations, (London, England), vol. XXVII, no 1, mars 1989, pp. 93-111.

"Trade Union Membership and Activism Among Young People in Great Britain», by Joan Payne, British Journal of Industrial Relations, (London, England), vol. XXVII, no 1, mars 1989, pp. 111-133.

«Learning from Clerical Unions: Two Cases of Organizing Success», by Richard W. Hurd, Labor Studies Journal, (Rutgers Univ., New Brunswick, N.J.), vol. 214, no 1, 1989, pp. 30-52. 
"Research on Union Commitment: Implications for Labor», by Daniel G. Gallagher and Paul F. Clark, Labor Studies Journal, (Rutgers Univ., New Brunswick, N.J.), vol. 14, no 1, 1989, pp. 52-72.

"Labourism and Economic Action: The Halifax Shipyards Strike of 1920», by Suzanne Morton, Labour/Le travail, (St. John's, Newfoundland), no 22, 1989, pp. 99-139.

"Interstate vs Interprovincial Differences in Union Density», by Noah M. Meltz, Industrial Relations, (Univ. of California, Berkeley), vol. 28, no 2, 1989, pp. 142-159.

«Trade Agreement vs Open Shop: Employers' Choices Before WW1», by Jeffrey Haydu, Industrial Relations, (Univ. of California, Berkeley), vol. 28, no 2, 1989, pp. 159-174.

«Spanning the Union/Nonunion Boundary», by Peter Cappelli and Peter D. Sherer, Industrial Relations, (Univ. of California, Berkeley), vol. 28, no 2, 1989, pp. 206-227.

\section{Droit du travail}

"Vote du président et pouvoirs de la majorité dans les délibérations du comité d'entreprise», par Jean Savatier, Droit social (Paris), no 3, mars 1989, pp. 206-215.

«Le fonctionnement interne du comité d'entreprise dépend-il d'un accord? Cour de cassation, chambre sociale 15 janvier 1989», conclusions de l'avocat général Georges Picca, Droit social, (Paris), no 3, mars 1989, pp. 215-220.

«La rigidité de la procédure en matière d'extension des conventions et accords collectifs du travail», par Denise Aufrère-Philbert, Droit social, (Paris), no 3, 1989, pp. 237-242.

«Formalisme et consensualisme dans la constitution des syndicats et des sections syndicales», par Jean Savatier, Droit social, (Paris), no 4, avril 1989, pp. 304-311.

"La jurisprudence professionnelle et sociale de la Cour de justice des Communautés européennes en 1988", par Jean Boulouis, Droit social, (Paris), no 4, avril 1989, pp. 337-342.

«Le droit syndical selon l'article 2 de la convention no 87. Que signifie l'expression 'tous les travailleurs sans distinction d'aucune sorte?'», par Jane Hodges-Aeberhard, Revue internationale du travail, (Genève), vol. 128, no 1, 1989, pp. 197-217.

«Changement de cap de la législation du travail en Nouvelle-Zélande. La loi de 1987 sur les relations de travail», par A.J. Geare, Revue internationale du travail, vol. 128, no 2, 1989, pp. 237-255.

«Décisions judiciaires en matière de droit du travail», Revue internationale du travail, (Genève), vol. 128, no 2, 1989, pp. 255-277.

«Relations de travail: peut-on congédier l'employé en probation se prétendant victime d'une lésion professionnelle?», INFO, (Montréal), vol. 12, no 9, 1989, pp. 10-12.

«Trends and Developments in Industrial Relations and Industrial Relations Law: Trade Union Discipline and Non-Strikes», by John Gennard, Mairi Steele and Kenneth Miller, Industrial Relations Journal, (Univ. of Nottingham, England), vol. 20, no 1, 1989, pp. 5-16.

"The Canadian Charter, Freedom of Association and Labour Relations», by Andy Khan, Industrial Relations Journal, (Univ. of Nottingham, England), vol. 20, no 1, 1989, pp. 47-54.

"Technological and Organizational Change in Canada», by Peter Senker, New Technology, Work and Employment, (Oxford, England), vol. 4, no 1, 1989, pp. 54-65.

"Technical Change, Work Organization and Training: Some Issues Relating to the Role of Market Forces", by Michael Wiedermeyer, New Technology, Work and Employment, (Oxford, England), vol. 4, no 1, 1989, pp. 54-66. 
"La réintégration du gréviste illégalement licencié», par Jean-Emmanuel Ray, Droit social, (Paris), no 5, 1989, pp. 349-361.

«La promotion de l'article L. 122-3-1 du Code du travail relative aux contrats de travail à durée déterminée irréguliers», par Guy Poulain, Droit social, (Paris), no 5, 1989, pp. 361-369.

\section{Gestion des ressources humaines et des organisations}

«24 heures dans la vie d'un PDG», par Hélène Reginster, Commerce, (Montréal), no 6, 1989, pp. 174-185.

«Strategic Intent», by Gary Hamel and C.K. Prahalad, Harvard Business Review, (Boston), no 3, 1989, pp. 63-77.

«La gestion intégrale de la qualité, une philosophie de gestion», par Joseph Kélada, Gestion, (Montréal), vol. 14, no 1, 1989, pp. 8-15.

«La nature (humaine), la conduite de la vie et la gestion», par Jean-Pierre Hogue, Gestion, (Montréal), vol. 14, no 1, 1989, pp. 31-39.

«Une grille des capacités individuelles du personnel comme outil de gestion prévisionnelle», par Frank Bournois et Jean Thomas, Gestion, (Montréal), vol. 14, no 1, 1989, pp. 39-49.

«Gestion prévisionnelle de l'emploi et des ressources humaines: de nouveaux outils d'apprentissage du changement?», par Louis Mallet, Formation/emploi, (Paris), no 25, 1989, pp. 66-78.

«La sécurité et l'hygiène du travail en Grèce: problèmes actuels», par A. Valavanidis et $\mathrm{N}$. Sarafopoulos, Revue internationale du travail, (Genève), vol. 128, no 2, 1989, pp. 277-289.

«La communication comme outil de développement des ressources», INFO, (Montréal), vol. 12, no 9, 1989, pp. 12-14.

«La réaffectation: partie intégrante de nos moeurs économiques», par Camille Labrecque, INFO, (Montréal), vol. 12, no 9, 1989, pp. 20-22.

"Technology and Change in Bureaucratic Cultures», by Sherry Devereaux Ferguson and Stewart Ferguson, Optimum, (Ottawa), vol. 19, no 3, 1989, pp. 41-72.

«Le principe du mérite par rapport à l'ordre de démérite», par R. Claude Boucher, Optimum, (Ottawa), vol. 19, no 4, 1989, pp. 98-107.

"The Stuff of Leadership Can be Learned. And Stanford Must Provide the 21st-Century World with Leaders of Great Breadth, Versality, and Understanding», by John Gardner, Stanford Business School Magazine, (Stanford, Calif.), vol. 57, no 2, 1988, pp. 20-24.

«Employee Selection Procedures», by Neal Schmitt, Work Place Topics (Wash., D.C.), AFLCIO, Department of Economic Research, vol. 1, no 2, 1988, pp. 3-16.

«The Polygraph and Paper-and-Pencil Honesty Tests as Employee Screening Procedure», by Paul R. Sackett, Work Place Topics, (Wash., D.C.), vol. 1, no 2, 1988, pp. 16-24.

«Employee Selection Devices: Questions Unions Ask», by Helen De Haven, Work Place Topics, (Wash., D.C.), vol. 1, no 2, 1988, pp. 24-27.

«Improving Productivity and Quality Through Collaboration», by William N. Cooke, Industrial Relations, (Univ. of California, Berkeley), vol. 28, no 2, 1989, pp. 299-319.

«La détermination des bénéficiaires de la participation des salariés aux résultats de l'entreprise», par Jean Savatier, Droit social, (Paris), no 5, 1989, pp. 381-388. 


\section{Sociologie du travail}

«Institutional Barriers to Employment of Older Workers», by Diane E. Herz and Philip L. Rones, Monthly Labor Review, (Wash., D.C.), vol. 112, no 4, 1989, pp. 14-22.

"'CAD - The 'Taylorisation' of Drawing Office Work", by Ian McLoughlin, New Technology Work and Employment, by Jon Clark, (Oxford, England), vol. 4, no 1, 1989, pp. 5-18.

"High Technology and the New International Division of Labour», by Manuel Castells, Labour and Society, (Geneva), vol. 14, 1989, pp. 7-43.

"Time and Work During Early American Industrialism», by David Brody, Labor History, (New York), vol. 30, no 1, 1989, pp. 5-47.

«From the Barricades of Paris to the Sidewalks of New York: German Artisans and the European Roots of American Labor Radicalism", by Stanley Nadel, Labor History, (New York), vol. 30, no 1, 1989, pp. 74-76.

«Labor and the 1966 Elections», by Alan Draper, Labor History, (New York), vol. 30, no 1, 1989, pp. 76-93.

«La décentralisation, histoire d'une idée», par Joseph Krulic, Projet, (Paris), no 216, 1989, pp. 77-87.

«La participation: pour un développement équitable», par Denis Goulet, Travail et société, (Genève), vol, 14, no 1, 1989, pp. 1-25.

«Industrial Discipline: Factory Regime and Politics in Lancaster», by Alan Warde, Work, Employment and Society, (London, England), vol. 3, no 1, 1989, pp. 49-65.

«State Ownership and the Problem of the Work Incentive: An Egyptian Case Study», by John S. Henley and Mahamed M. Ereisha, Work, Employment and Society, (London, England), vol. 3, no 1,1989 , pp. 65-89.

«Age-Dependence and Historical Effects on the Failure Rates of Worker Cooperatives: An Event-History Analysis), by Patrick Kenis, Economic and Industrial Democracy, (Stockholm, Sweden), vol. 10, no 1,1989 , pp. 59-81.

\section{Économique du travail, main-d'oeuvre, sécurité sociale}

«Dix ans d'insertion des diplômés universitaires», par Alain Charlot et François Pottier, Formation/Emploi, (Paris), no 25, 1989, pp. 3-19.

"L'évolution de la formation continue dans les secteurs d'activité (1973-1985), Formation/Emploi, (Paris), no 25, 1989, pp. 19-39.

«La contribution de la mobilité interne à la déformation des structures de l'emploi dans l'industrie», par Gérard Podevin, Formation/Emploi, (Paris), no 25, 1989, pp. 39-56.

«La déformation de la structure des emplois: un exemple régional», par Michel Bellet et Christian Le Bas, Formation/Emploi, (Paris), no 25, 1989, pp. 56-66.

«Le travail des jeunes, les relations professionnelles et les politiques sociales dans les économies avancées», par Paolo Garonna et Paul Ryan, Formation/Emploi, (Paris), no 25, 1989, pp. 78-91.

"Néo-libéralisme et protection sociale: la question de la privatisation dans les pays de la CEE», par Alain Euzeby et Jef van Langendonck, Droit social, (Paris), no 3, mars 1989, pp. 256-266.

«Nouvelles formes d'emploi et précarité: comparaisons internationales», par Jacques Freyssinet, Droit social, (Paris), no 4, avril 1989, pp. 293-300. 
«La sécurité sociale et l'échéance de 1992», par André Laurent, Droit social, (Paris), no 4, avril 1989, pp. 345-348.

«L'évolution technologique et son impact sur la gestion des organismes de sécurité sociale», par H. Doggette, Revue internationale du travail, no 4, 1988, pp. 399-414.

"Les techniques de relations publiques utilisées par les régimes de sécurité sociale et leur impact: l'expérience de l'Australie", par Brendan Godfrey, Revue internationale de sécurité sociale, (Bruxelles), no 4, 1988, pp. 430-454.

«The Effects of Flexible Specialization on Industrial Politics and the Labor Market: The Motion Picture Industry», by Susan Christopherson and Michael Storper, Industrial and Labor Relations Review, (Cornell Univ., Ithaca, N.Y.), vol. 42, no 3, 1989, pp. 331-348.

«Labor Market Completes Sixth Year of Expansion», by W.J. Hoew, W. Parks, Monthly Labor Review, (Wash., D.C.), vol. 112, no 2, 1989, pp. 3-15.

"Comparing U.S. and Japanese Labor Markets", by R.W. Bednarzik and C.R. Shiels, Monthly Labor Review, (Wash., D.C.), vol. 112, no 1, 1989, pp. 31-43.

«Productivity in the Carburetors, Pistons, and Valves Industry», by J.W. Ferris, V.L. Klarquist, Monthly Labor Review, (Wash., D.C.), vol. 112, no 1, 1989, pp. 43-47.

"What Temporary Workers Earn: Findings form New BLS Survey», by Harry B. Williams, Monthly Labor Review, (Wash., D.C.), vol. 112, no 2, 1989, pp. 3-7.

«How Firms Adjust to the Shift Toward Contingent Workers», by Richard S. Belous, Monthly Labor Review, (Wash., D.C.), vol. 112, no 3, 1989, pp. 7-13.

«Productivity Continued to Rise in Many Industries During 1987», by Arthur S. Herman, Monthly Labor Review, (Wash., D.C.), vol. 112, no 3, 1989, pp. 13-21.

«Sources of Increasing Inequality in Wages and Salaries, 1960-80», by W.N. Grubb, and R.H. Wilson, Monthly Labor Review, (Cornell Univ., Ithaca, N.Y.), vol. 112, no 4, 1989, pp. 3-14.

«Unemployment Insurance in the U.S. and Europe, 1973-83», by Beatrice G. Reubens, Monthly Labor Review, (Wash., D.C.), vol. 112, no 4, 1989, pp. 22-32.

«Multifactor Productivity Slips in the Nonrubber Footwear Industry», by John Duke, and Lise Usher, Monthly Labor Review, (Wash., D.C.), vol. 112, no 4, 1989, pp. 32-44.

"High Tech and Labour in the Asian NICs», by Pang Eng Fong and Linda Y.C. Lim, Labour and Society, (Geneva), vol. 14, 1989, pp. 43-59.

«Labour and State Policy in the Technological Development of the Hong Kong Electronics Industry», by Jeffrey Henderson, Labour and Society, (Geneva), vol. 14, 1989, pp. 103-127.

«On Theories of Unemployment Persistence: A Quick Look at Recent Developments», by Jean-Paul Fitoussi and Jacques Le Cacheux, Labour, (Roma), vol. 2, no 2, 1988, pp. 3-21.

"Can Europe Reach Full Employment Again?», by Paolo Sylos Labini, Labour, (Roma), vol. 2, no 2, 1988, pp. 57-71.

"A Small and Large Establishments, Employment Growth and Structural Change», by Tito Boeri, Labour, (Roma), vol. 2, no 2, 1988, pp. 155-184.

«Microelectronics and Manpower in China», by Malcolm Warner, New Technology Work and Employment, (Oxford, England), vol. 4, no 1, 1989, pp. 18-27.

"Water Notes Dry Up: The Impact of the Donavan Reform Proposals and Thatcherism at Work on Labour Productivity in British Manufacturing Industry", by David Metcalf, British Journal of Industrial Relations, (London, England), vol. XXVII, no 1, 1989, pp. 1-33.

"The Relationship Between Youth and Adult Award Wages from 1930 to 1985», by Christine Short, The Journal of Industrial Relations, (Univ. of New South Wales, Kensington, Australia), vol. 30, no 4, 1988, pp. 491-511. 
«Employee Participation in a Japanese Owned British Electronics Factory: Reality or Symbolism?», by Philip Lewis, Employee Relations, (Bradford, England), vol. 11, no 1, 1989, pp. 3-10.

«Payment Systems and Performance Improvement: Participation in Payment System Design», by Angela Bowey and Richard Thorpe, Employee Relations, (Bradford, England), vol. 11, no 1, 1989, pp. 17-21.

«Job Stress: Boon as Well as Bane», by A.J. Geare, Employee Relations, (Bradford, England), vol. 11, no 1, 1989, pp. 21-27.

«Le bonheur socio-économique», par Diane Bellemare et Lise Poulin Simon, Magazine Avenir, (Montréal), vol. 3, no 3, 1989, pp. 21-27.

«Technological Innovation and Employment in Telecommunications», by Lise M. Lynch and Paul Osterman, Industrial Relations, (Univ. of California, Berkeley), vol. 28, no 2, 1989, pp. 188-206.

«Market Structure, Strike Activity, and Union Wage Settlements», by John M. Abowd and Joseph S. Tracy, Industrial Relations, (Univ. of California, Berkeley), vol. 28, no 2, 1989, pp. 227-251.

"Wage Structure and Dynamics in the Electronics Industry», by Jonathan S. Leonard, Industrial Relations, (Univ. of California, Berkeley), vol. 28, no 2, 1989, pp. 251-276.

«Une stratégie de développement économique et régional axée sur la valeur ajoutée et sur l'emploi», par Diane Bellemare et Lise Poulin Simon, Travail et société, (Genève), vol. 14, no 1, 1989, pp. 45-71.

«L'évolution des structures par secteur: les gagnants et les perdants», par Hans-Friedrich Eckey, Travail et sociéte, (Genève), vol. 14, no 1, 1989, pp. 71-89.

«Political and Economic Determinants of Strikes in Israël: A Sectorial Comparison», by Yonatan Reshef and Brian Bemmels, Economic and Industrial Democracy, (Stockholm, Sweden), vol. 10, no 1, 1989, pp. 35-59.

«Casual Work and Owner Occupation», by Janet Ford, Work, Employment and Society, (London, England), vol. 3, no 1, 1989, pp. 29-49.

«La clause de dédit-formation ou le régime de liberté surveillée appliqué aux salariés», par Jean-Pierre Chauchard, Droit social, (Paris), no 5, 1989, pp. 388-394.

\section{Femmes et travail}

«L'emploi des jeunes femmes: Actes de la journée d'étude organisée le 13 mai 1987 par la Commission du travail des femmes», Revue du travail, (Bruxelles), no 5, 1988, pp. 349-373.

«The Unemployment Rates of Men and Women: A Transition Probability Analysis», by Larry DeBoer and Michael C. Seeborg, Industrial and Labor Relations Review, (Cornell Univ., Ithaca, N.Y.), vol. 42, no 3, 1989, pp. 404-415.

"The Gender Gap in Earnings During World War II: New Evidence», by Mark Aldrich, Industrial and Labor Relations Review, (Cornell Univ., Ithaca, N.Y.), vol. 42, no 3, 1989, pp. 415-430.

"Families of Working Wives Spending more on Services, Nondurables», by Eva Jacobs and others, Monthly Labor Review, (Wash., D.C.), vol. 112, no 2, 1989, pp. 15-24.

«Do Women Cause Unemployment? Evidence from Eight OECD Countries», by Mary McCarthy and Lucrezia Reichlin, Labour (Roma), vol. 2, no 2, 1988, pp. 71-101. 
«Femenization of the Labour Process in the Communications Industry: The Case of the Telephone Operators, 1876-1904", by Michèle Martin, Labour/Le Travail, (St. John's, Newfoundland), no 22, 1989, pp. 139-163.

«Sécurité du travail et ordre public», par Hubert Seillan, Droit social, (Paris), no 5, 1989, pp. 376-381.

\section{LIVRES REÇUS BOOKS RECEIVED}

BUREAU INTERNATIONAL DU TRAVAIL, La négociation collective dans les pays industrialisés à économie de marché: un réexamen, Genève, 1989, $351 \mathrm{pp}$., ISBN 92-2-205606-X.

WEIERMAIR, Klaus, The Labour Market and the Service Sector, Vancouver, B.C., The Fraser Institute, 1988, $118 \mathrm{pp}$., ISBN 0-088975-142-0 and ISSN 0835-4227.

GRUBEL, Herbert G. and Michael A. WALKER, Service Industry Growth. Causes and Effects, Vancouver, B.C., 1989, 279 pp., ISBN 0-88975-128-5 and ISSN 0835-4227.

WATSON, William G., The Economics of Canadian Leisure, Vancouver, B.C., The Fraser Institute, 1988, $163 \mathrm{pp.,}$ ISBN 0-88975-146-3 and ISSN 0835-4227.

WEST, Edwin G., Higher Education in Canada. An Analysis, Vancouver, B.C., The Fraser Institute, 1988, 122 pp., ISBN 0-88975-107-2 and ISSN 0835-4227.

HAMMES, David L., Shaping our Nation. An Economic Analysis of Canada's Consulting Engineers, Vancouver, B.C., The Fraser Institute, 1988, $165 \mathrm{pp}$., ISBN 0-88975-113-7 and ISSN 0835-4227.

McFETRIDGE, Donald G. and Douglas A. SMITH, The Economics of Vertical
Disintegration, Vancouver, B.C., The Fraser Institute, 1988, 115 pp., ISBN 0-88975-134 and ISSN 0835-4227.

GILL, David, The Market for Legal Services, Vancouver, B.C., The Fraser Institute, 1988, 100 pp., ISBN 0-88975-130-7 and ISSN 0835-4227.

BERNSTEIN, Jeffrey I, and Randall $R$. GEEHAN, The Insurance Industry in Canada, Vancouver, B.C., The Fraser Institute, 1988, 93 pp., ISBN 0-88975-111-0 and ISSN 0835-4227.

CHANT, John F., The Market for Financial Services. Deposit-Taking Institutions, Vancouver, B.C., The Fraser Institute, 1988, 135 pp., ISBN 0-88975-126-9 and ISSN 0835-4227.

AULD, Douglas and Harry KITCHEN, The Supply of Government Services, Vancouver, B.C., The Fraser Institue, 1988, 123 pp., ISBN 0-88975-138-2 and ISSN 0835-4227.

ACHESON, Keith and Stephen FERRIS, Retail and Wholesale Trade Services in Canada, Vancouver, B.C., The Fraser Institute, 1988, 161 pp., ISBN 0-88975-122-6 and ISSN 0835-4227.

PALDA, Kristian S., The Role of Advertising Agencies in Canada's Service Sector, 